\title{
Effects of Terms of Trade Shocks on the Russian Economy
}

\author{
Natalia Turdyeva, Bank of Russia \\ turdyevana@mail.cbr.ru
}

The principal interest of the paper is the quantification of terms of trade shocks response of the Russian economy on a detailed computable general equilibrium (CGE) model calibrated with Russian input-output data. The results suggest a decrease in the welfare of the representative consumer and real GDP with the deterioration of the terms of trade. In the Central scenario (a $10 \%$ decrease in the world price of crude oil, a $3 \%$ decrease in the world price of natural gas, and a $8 \%$ decrease in the world price of petroleum products) welfare of the representative consumer decreases by $-1.17 \%$ of the benchmark consumption level, or $-0.58 \%$ of the base year GDP in the comparative static model. The percentage change of the GDP in the Central scenario of the comparative static model is of the same magnitude as the decrease in representative consumer's welfare in terms of the benchmark GDP $(-1.55 \%)$. Welfare changes associated with the Central scenario of the steady-state model, where capital stock adjusts to its long-term level, indicate a significant decrease in the welfare of the representative consumer up to $-2.64 \%$ of the benchmark consumption level, or $-1.23 \%$ of the base year GDP. Percentage change of the GDP in the Central scenario of the steady-state model exceeds representative consumer's decrease in welfare in terms of the benchmark GDP $(-2.51 \%)$. The model was validated by historical simulation with observed levels of exogenous parameters, mimicking change in economic environment from 2011 to 2015. The results of the historical simulation stress the importance of fiscal parameters (i.e. export taxes) in analysis of production behaviour of Russian extraction industries.

Keywords: terms of trade, oil price shock, computable general equilibrium models, input-output table, industry output, CGE model validation

JEL Codes: F17, C68, D58
Citation: Turdyeva, N. (2020). Effects of Terms of Trade Shocks on the Russian Economy. Russian Journal of Money and Finance, 79(2), pp. 43-69.

doi: $10.31477 /$ rjmf.202002.43

\section{Introduction}

The paper focuses on the Russian economy's response to a negative terms of trade shock. The aim is to study the propagation of oil price shock in the simplest general equilibrium settings possible, in a small open nested-CES economy with 
heterogeneous economic agents, perfectly competitive cost-minimising producers, and inelastic factor supplies. This paper examines the impact of changes in world prices on the Russian economy. In particular, I am interested in the change in production as a result of changes in world prices for the main Russian export and import commodities.

A number of recent macro studies (Atalay, 2017; Acemoglu et al., 2017; Burstein et al., 2008) stress importance of explicit introduction of the intermediates in the models assessing effects of external shocks, which is a well-established practice in the computable general equilibrium methodology. Models of this class permit introduction of rich details and complex production structures as well as optimising behaviour of economic agents.

The model presented in the paper belongs to the class of CGE models. It has a detailed industry structure, which allows tracing the effect of changes in world prices on all aspects of the Russian economy.

The results suggest a decrease of welfare of the representative consumer and real GDP with the deterioration of the terms of trade. In the Central scenario (a 10\% decrease in the world price of crude oil, a 3\% decrease in the world price of natural gas and a $8 \%$ decrease in the world price of petroleum products) welfare of the representative consumer decreases by $-1.17 \%$ of the benchmark consumption level, or $-0.58 \%$ of the base year GDP in the comparative static model. The percentage change of GDP in the Central scenario of the comparative static model is of the same magnitude as representative consumer's decrease in welfare in terms of the benchmark GDP (-1.55\%).

Welfare changes associated with the Central scenario of the steady-state model indicate a significant decrease in the welfare of the representative consumer up to $-2.64 \%$ of the benchmark consumption level, or $-1.23 \%$ of the base year GDP. The percentage change of the GDP in the Central scenario of the steadystate model exceeds representative consumer's decrease in welfare in terms of the benchmark GDP (-2.51\%). The GDP response in the steady-state model is in line with estimates obtained in compatible work (Polbin, 2017).

These results exceed welfare changes in the Central scenario of the static model, and we can refer to these values as upper bound of possible changes in welfare in the dynamic modelling exercise (Rutherford and Tarr, 2003).

\section{Literature review}

\subsection{The effect of the terms of trade shock on industrial output}

The dependence of the Russian economy on oil prices manifests itself in 2014-2015 when, following the reduction in oil prices and the restriction of access to capital markets, Russia's economy entered a recession (World Bank Group, 2015).

The main reasons for the decline in production in 2015 were a sharp drop in oil prices and a subsequent depreciation of the ruble with a corresponding increase 
in inflation. The situation was complicated by the loss of investor's confidence resulting from economic, political, and external economic circumstances.

The decline in prices for oil and oil products, which are the key Russian exports, while maintaining world prices for goods imported into Russia, led to a reduction in the ratio of prices of export goods to the prices of imported goods, or terms of trade (Reinsdorf, 2010).

Numerous studies (International Monetary Fund, 2017a; De V. Cavalcanti et al., 2015) find that GDP growth (see Figure 1) and other macroeconomic characteristics of commodity-exporting countries, including Russia, depend to a greater extent on changing terms of trade than comparable countries, which are not commodity exporters.

Figure 1. Contribution of terms of trade to GDP per capita change, commodityexporting countries and emerging market and developing economies (EMDE), in average for developing countries

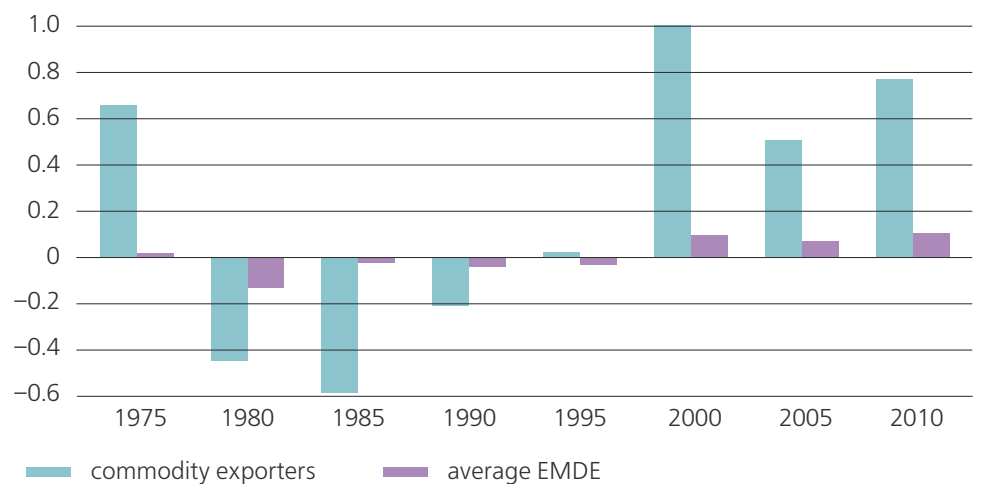

Source: International Monetary Fund (2017a, p. 74)

There are various estimates of the extent to which the shocks of the terms of trade cause business cycles in developing countries. For a long time economists considered that up to $30 \%$ of the change in output and other macroeconomic indicators was due to changes in terms of trade (Mendoza, 1995; Kose, 2002). The latest estimates (SchmittGrohé and Uribe, 2018) significantly reduce this estimate, referring to less than $10 \%$ of the relationship between changes in terms of trade and the movement of gross output. Despite the uncertainty about the impact of the terms of trade on the economy of developing countries on average, the mechanisms of influence are well described. Idrisov et al. (2015) note two main channels of the impact of terms of trade on the Russian economy: a reduction in disposable income and devaluation of the ruble.

The impact of the real ruble exchange rate on the macroeconomic parameters of the economy and aggregate output has always been in the focus of attention of economists. Let us consider below a few works devoted to this topic in general and in application to the Russian economy. 


\subsection{Total output and real exchange rate}

There is no consensus in theoretical literature on the impact of a change in the exchange rate of the national currency on the real output. Gylfason and Schmid (1983) discuss a possible channel for the negative impact of the weakening of the national currency on aggregate output: in the case of a large share of imports in intermediate consumption, devaluation leads to an increase in the costs of domestic production, which can cause a fall in supply and, as a consequence, a reduction in the equilibrium output. This channel of influence is the more important, the less the elasticity of substitution of imported intermediates by domestic in the production processes of domestic firms.

For the economy as a whole, the substitution of imported by domestic goods largely depends on the structure of the preferences of households: if imports and domestically produced goods are easily substituted in the consumption, then with the increase in import prices there will be a switch to consumption of domestic goods and, as shown in the work of Kadochnikov et al. (2003), this will lead to an increase in the domestic output. If domestic and imported goods are complements and do not replace each other in consumption, the increase in import prices will be accompanied by a decrease in demand for home products, which is due to the predominance of the income effect over the substitution effect and, as a result, the demand for home products will decrease.

An important channel of propagation of exchange rate swings on the aggregate output that may be the relationship of exchange rate and investment demand. As noted in a number of growth models with technology adaptation (Easterly et al., 1994), the weakening of the national currency leads to a rise in the cost of borrowing technology. This leads to a drop in investment and, ultimately, to a decrease in the aggregate output. As Badasen et al. (2015) note, this channel of influence is especially important for developing economies in which technology import plays an important role.

In the works of Aghion et al. (2000), Greenwald and Stiglitz (1993), Gatti et al. (2007), it is shown that in the case of a large volume of borrowings of the private sector in foreign currency, after a devaluation, debt servicing becomes more complicated due to its growth in the national currency. This can lead to a reduction in the cumulative output.

The general direction of the change in the aggregate and industry output caused by the exchange rate changes depends on the conditions prevailing at a particular moment in the given economy, and economic theory does not give a single answer to the question of the direction of change. In part, this thesis is confirmed by the heterogeneous results obtained for the Russian economy in the studies of various authors over the past few years.

Dynnikova (2000), on the basis of the theoretical model, came to the conclusion that in the period from 1993 to 1997, the strengthening of the real exchange rate 
of the ruble was accompanied by an increase in output, presumably due to lower prices for imported components and intermediate goods.

Kontorovich's empirical findings (Kontorovich, 2001) show that strengthening of the ruble/dollar real exchange rate by $1 \%$ with a lag of several months is accompanied by a reduction in the intensity index of industrial production by approximately $0.2 \%$.

In the work of Kadochnikov et al. (2003), a link is made between the strengthening of the national currency and the growth in demand for imports: the strengthening of the real exchange rate by $1 \%$ leads to the replacement of domestic goods with imports by $0.77 \%$ on average in the economy.

Kartaev (2009) concludes that the weakening of the national currency by $1 \%$ leads to an increase in real GDP of Russia by $0.66 \%$. From the point of view of sector dynamics, the weakening of the ruble does not lead to changes in the production of the extractive industry, but at the same time, it leads to an increase in the output of the manufacturing industry.

Vdovichenko et al. (2003) also express the idea that the manufacturing industry reacts more strongly to fluctuations in exogenous factors, including the real exchange rate. From the point of view of the difference in the sectoral response to the change in the real exchange rate, the industries were divided into three groups: losers of the strengthening the real exchange rate (fuel, wood pulp and paper, chemical and petrochemical, non-ferrous metallurgy), insensitive to real exchange rate changes (food and mechanical engineering), and winners (light industry, ferrous metallurgy, construction materials industry, and electric power industry).

In the work of Badasen et al. (2015), based on econometric research, it is concluded that when the exchange rate of the ruble depreciates, the most favourable effect is on export-oriented industries, as well as on industries with a low share of imports in costs.

The studies referred above generally agree with the positive influence of the relative weakening of the domestic currency on domestic output. However, it should be noted that in a case of a terms-of-trade (ToT) shock, usually both channels of influence are present: income effect and exchange rate. Thus, in order to simulate effect of a ToT deterioration of the detailed industry structure of the Russian economy, there is a need of a structural model. One of possible solutions is use of the computable general equilibrium model.

\subsection{Estimating effects of a ToT shock with a general equilibrium mode}

The computable (applied) general equilibrium model is a system of equations describing behaviour of economic agents in the economy. The numerical parameters of the model equations are based on statistical data of one year or 
averaged data over several years. The procedure for calculating the parameters of a model is called calibration. The model is calibrated so that the base year data is obtained as the initial equilibrium.

Scenario forecasts are set by changing one or several controls, for example, by changing exogenous world prices for export or import goods. After changing the controls, a new equilibrium is obtained. The new equilibrium reflects the effect of the proposed changes in the controls. Resulting changes in endogenous variables are obtained by comparing the basic data set and the new equilibrium obtained as a result of the experiment.

CGE models have traditionally been the most effective and most widely used for assessing possible changes in foreign trade (Hertel, 2013), taxation (Dixon and Rimmer, 2016), public expenditure (Holmøy and Strøm, 2013), social security (Fehr, 2016), demography (Zodrow and Diamond, 2013), immigration (Fehr et al., 2013), labour markets (Dixon et al., 2013), environment (Böhringer et al., 2015), as well as assessing the effects of natural (Shibusawa and Miyata, 2011) and man-made disasters (Rose and Liao, 2005). CGE models are the only practical way to quantify these effects at the level of industries, regions (Giesecke and Madden, 2013), and socio-economic groups (Horridge et al., 2013).

Even at the dawn of existence, computable general equilibrium models were used to assess the effects of the shock of terms of trade on the welfare and changes in output and factor income (Devarajan and Robinson, 2013). Subsequently, a variety of studies were conducted both at the level of one country (Dixon et al., 2013), often in a regional breakdown (Dong et al., 2017), or in the framework of global models (Timilsina, 2015).

\subsection{Models of computable general equilibrium for the Russian economy}

Examples of the use of CGE models for Russia include Makarov (1999), Zemnitsky (2003), Bakhtizin (2003), Alekseev et al. (2003), Alekseev, Sokolov, et al. (2004), Jensen et al. (2004), Rutherford et al. (2005), Carbone et al. (2004), Tarr et al. (2005), Alekseyev et al. (2004), Besstremyannaya and Bakhtizin (2006), Volchkova et al. (2006), Rutherford and Tarr (2006), Kolik et al. (2015), and Böhringer et al. (2015).

The effects of the shock of the terms of trade and the subsequent recession of 2014-2015 on welfare distribution in Russia are considered in the work of Bussolo and Luongo (2017). The authors concluded that a 50\% reduction in oil prices would lead to a significant decline in oil production and refining $(-13 \%)$, and a reduction in construction industry production $(-5 \%)$ and transport $(-1.3 \%)$. The main gain will be for the export industries of manufacturing (+12.7\%), agriculture $(+9.5 \%)$, other manufacturing $(+8.2 \%)$ and other extractive industries $(+5.1 \%)$, and the food industry (+2.3\%). Among other consequences, the authors note a fall in the well- 
being of the population by $6.88 \%$ in terms of consumption. The general direction of changes in output in this paper are similar to those documented in the work of Bussolo and Luongo (2017), though I use a much more detailed industry structure. The contribution of the present paper is in the validation method with the use of historical simulations and actual statistical data. The validation method is described in Section 5.5.

\section{Model description}

I present two models: the core comparative static model with inelastic factor supply and a steady-state model with a variable capital stock. The steady-state model is an extension of the comparative static model, it solves for time-invariant capital stock, i.e. cost of investment equals the discounted stream of rents on installed capital. The goal of the steady-state model is to 'evaluate the upper bound of welfare gains in a Solow type model' (Rutherford and Tarr, 2003).

\subsection{The comparative static model}

The structure of the core model is close to the CRTS model used in Böhringer et al. (2015). The model is based on optimising behaviour of all economic agents, supply and demand balances in all markets for goods, services, and factors. Budgets are balanced for all agents.

The algebraic formulation presented in Appendix I corresponds to the core model of a small open nested-CES economy with perfectly competitive costminimising producers and inelastic factor supplies. Economic agents presented in the model are households, enterprises, investment sector, and government. Consumers of final and intermediate goods differentiate between domestic and imported goods, i.e. the Armington assumption (Armington, 1969) is used (Figure 2).

Figure 2. Structure of products differentiation in the model

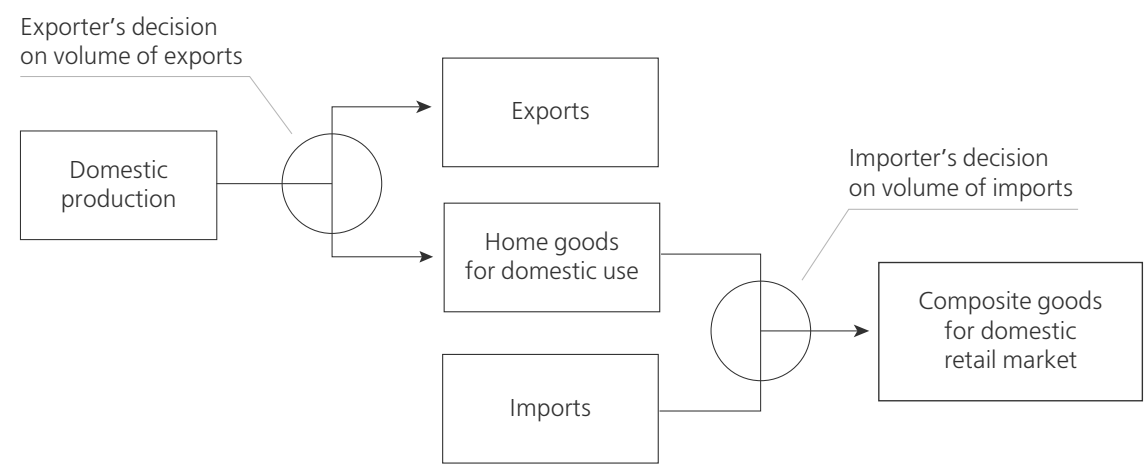




\subsubsection{Economic agents}

Economic agents of the model are: a representative household, enterprises, the government and a savings-investment bank (see Figure 3). The government collects direct and indirect taxes with fixed ad-valorem tax rates, saves an amount equal to trade surplus in the base year in foreign currency $(\bar{V})$, then saves a fixed portion of the tax revenue in the domestic savings-investment bank, and purchases goods $\left(g_{i}\right)$ on the final market.

Figure 3. Structure of income and spending of economic agents in the model

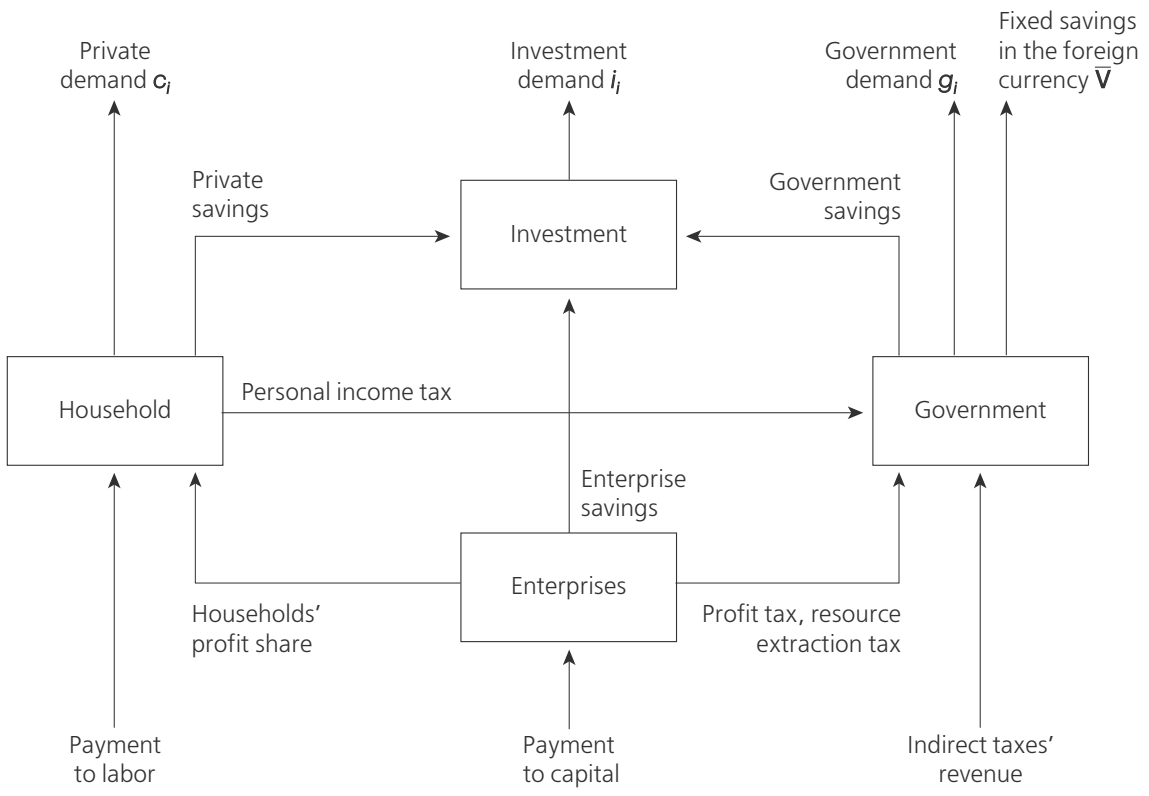

Source: compiled by the author

I assume that labour belongs to households and capital belongs to enterprises. Enterprises receive all capital income, pay direct corporate taxes (the corporate profit tax and the resource extraction tax), save a fixed portion of after-tax capital earnings and transfer the rest to shareholders. I assume that there is no foreign ownership of Russian companies, thus, all payments to shareholders are transferred to the domestic households.

The representative domestic household receives labour remuneration and share of profit from the enterprises (discussed above). Households pay personal income tax, save a portion of the after-tax income, and use the rest on private consumption $\left(c_{i}\right)$.

The savings-investment bank receives private, enterprise, and government savings. Savings of all economic agents in the model are savings-driven 
(Lofgren et al., 2002), in other words, each economic agent saves a fixed share of its budget. The savings-investment bank spends all available funds on purchase of goods on the final market $\left(i_{i}\right)$.

There is no international ownership of factors, i.e. the model does not account for non-zero net factor payments. Default external closure of the core model states that foreign savings of the government is fixed and exchange rate is fully flexible. The government's foreign savings are fixed on the base year level $\bar{V}$, which equals to the current account surplus (or, in the case of NFP $=0$, to the trade surplus).

\subsubsection{Industries}

There are 52 industries (Appendix II, Table 3) producing goods and services, each described by a representative firm. Cost-minimising firms operate in freeentry markets, which leads to zero profit, i.e. marginal returns for an individual firm equal marginal cost.

Production technologies are characterised by constant returns to scale. ${ }^{1}$ Output (Y) is a Leontief $\left(\sigma^{Y}=0\right)$ combination of value added (VA) and intermediate goods (INT). Value added is a Cobb-Douglas $\left(\sigma^{V A}=1\right)$ aggregate of primary factors: mobile labour (L), mobile (K) and specific capital (SK) (see Figure 4).

Figure 4. Structure of industrial production and supply of composite goods for the final market

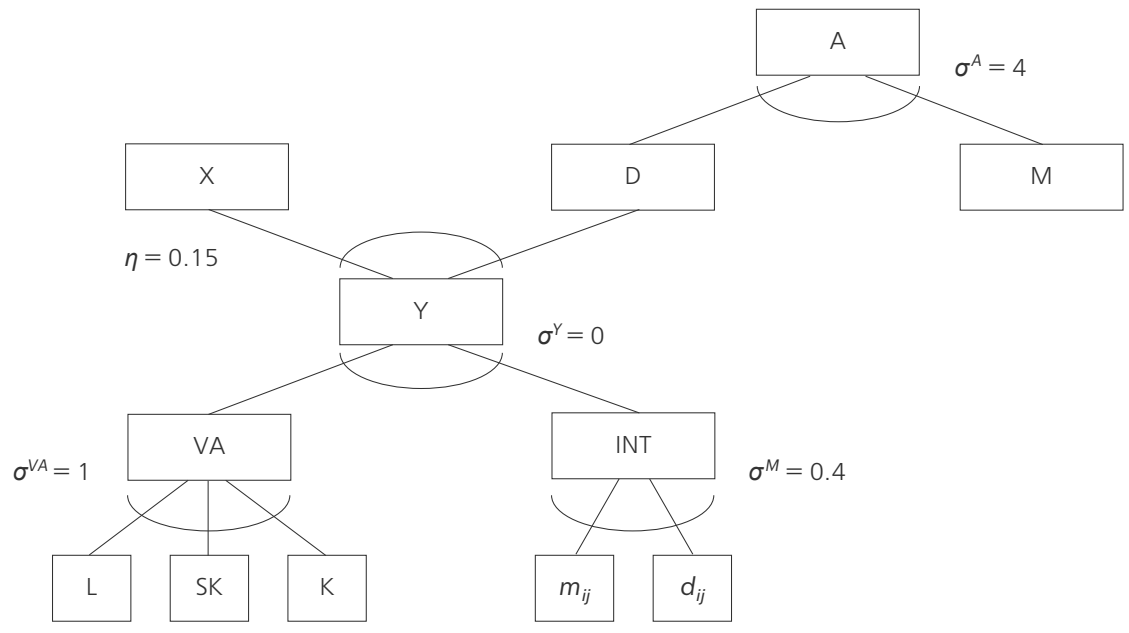

Source: compiled by the author

\footnotetext{
${ }^{1} \sigma_{Y}$ is the elasticity of substitution between value added (VA) and intermediate consumption (INT) in the upper-level production function. Notational convention: $\sigma$ denotes elasticity of substitution in various production and bundling functions; $\eta$ - elasticity of transformation between domestic goods for domestic market and exports. Note, that limit case of a CES function with elasticity of substitution $\sigma=0$ is the Leontief function, and $\sigma=1$ is the Cobb-Douglas function.
} 
Intermediate goods are a bundle of imported $\left(m_{i j}\right.$ - imports of commodity $i$ for industry $j$ ) and domestically produced intermediates $\left(d_{i j}\right)$. Bundling of domestic and imported intermediates is done for each industry and each type of goods separately. All bundling techniques for the intermediate products are described by CES functions and share the same low (Atalay, 2017) elasticity of substitution between domestic and imported goods $\left(\sigma^{m}=0.4\right)$, share parameters for each industry $i$ and each good $j$ are calibrated on detailed information provided by Russian inputoutput tables. ${ }^{2}$ Relatively low value of elasticity of substitution between domestic and imported intermediates reflects high level of complementarity of imports in firms' intermediate consumption (Berezinskaya and Vedev, 2015).

Domestically produced goods (Y) are split between domestic (D) and export markets $(\mathrm{X})$ on the basis of relative prices at home and export markets. This transformation, i.e. a decision of an exporter, is described by the constant elasticity of transformation (CET) function. Default value of elasticity of transformation $\eta$ equals 0.15 . This relatively low level of the elasticity of transformation corresponds to values reported in (Tokarick, 2014) and (International Monetary Fund, 2017b) and reflects problems in reallocation of resources from domestic supply to export markets that Russian economy faces.

Domestically produced goods for the domestic market (D) are bundled with imports (M). The composite product (A) is supplied to the domestic market where it serves final demand by economic agents. The bundling of domestic and imported goods is described by constant elasticity of substitution (CES) function with elasticity $\left(\sigma^{A}=4\right)$. This value is close to the average of Armington substitution elasticities between domestic and imported goods in GTAP 9 database (Aguiar et al., 2016).

\subsection{Steady-state model}

The steady-state model is an extension of the core comparative static model. The goal of the steady-state calculation is to evaluate the upper bound (Rutherford and Tarr, 2003) on welfare changes associated with terms of trade change for the Russian economy.

In the comparative static model the price of capital varies, while total supply of capital is fixed. In the steady-state model the mobile capital stock and investment demand are endogenously determined, while the price of capital is constant. In other words, the steady-state model solves for time-invariant capital stock. In the steady-state model optimal capital stock is such that cost of investment equals the discounted stream of rents on installed capital. ' $T$ This can be viewed as a multi-sector version of the "golden rule" equilibrium' (Rutherford and Tarr, 2003).

\footnotetext{
${ }^{2}$ Base input-output tables for the Russian Federation were estimated for year 2011, see at: https://www.gks.ru/accounts, more on data sources in the relevant section. Information on the composition of intermediate consumption is provided by use tables for domestic and imported goods.

${ }^{3}$ In this version of the model depreciation is set to zero.
} 


\section{Benchmark dataset}

The dataset for the model consists of two sets: economic indicators, which describe economy of the Russian Federation for the base year (2011) in the form of the Social accounting matrix (SAM) (see Section 4.1), and the second set of behavioural parameters derived from the relevant literature, which consists of different elasticities of substitution (see Section 4.2).

\subsection{Social accounting matrix}

The social accounting matrix for the model describes a snapshot of the economic activities of Russia in 2011, which is the base year in our case. The SAM is a square matrix, each account is represented by a row and a column (Pyatt, 1991). Row entities correspond to income of the respective account, while column depicts payments of the account. Accounts of the SAM consist of production activities, goods, factors of production, economic agents, and economic policy instruments. For more information on the social accounting matrix format of representing the economic data, see Pyatt and Round (1985).

Main sources of the data for the SAM are Russian Input-Output (IO) tables for $2011,{ }^{4}$ as well as National accounts for 2011 (Rosstat, 2017). The IO tables consist of a resource table, use tables in buyers' and basic prices, use tables of domestically produced and imported products, tables with transport and trade margins, and a table of taxes. Sectoral and commodity details of the original tables were aggregated to 52 commodity and industries (Appendix II, Table 3). Development of a dataset for a CGE model from an IO table is a well-documented process (Rutherford and Paltsev, 1999).

The IO tables do not contain information on direct taxes and other transfers between economic agents. This information was obtained from national accounts.

An aggregated version of the SAM used in the model is presented in the Appendix IV (Table 13).

\subsection{Elasticities}

The upper-level elasticity of substitution between value added and intermediate consumption in the production function equals zero $\left(\sigma^{Y}=0\right)$, indicating Leontief function. This type of nested production function was used in several models of the Russian economy (see Böhringer et al., 2015).

\footnotetext{
${ }^{4}$ Rosstat, 2017, Russian IO tables for 2011, see at: https://www.gks.ru/accounts. The 2011 IO tables were the most comprehensive source of the information on intersectoral linkages in the Russian economy at the time of the research.
} 
Value added is a Cobb-Douglas aggregate ${ }^{5}\left(\sigma^{V A}=1\right)$ of primary factors: mobile labour, mobile and specific capital (see Figure 4).

All bundling techniques for the intermediate products are described by CES functions and share the same elasticity of substitution between domestic and imported goods $\left(\sigma^{m}=0.4\right)$ (Atalay, 2017).

Transformation of domestically produced goods between domestic and export markets is described by the constant elasticity of transformation function $(\eta=0.15)$ (Tokarick, 2014; International Monetary Fund, 2017b).

The bundling of domestic and imported goods is described by constant elasticity of substitution function with elasticity $\left(\sigma^{A}=4\right.$ ) (Aguiar et al., 2016) (Table 1).

Table 1. Central values of elasticities in the model

\begin{tabular}{cllll} 
& Elasticity & Description & Value & Reference \\
\hline 1 & $\eta$ & $\begin{array}{l}\text { Elasticity of transformation between supply to } \\
\text { domestic and export markets }\end{array}$ & 0.15 & $\begin{array}{l}\text { Tokarick, 2014; International } \\
\text { Monetary Fund, 2017b }\end{array}$ \\
\hline 2 & $\sigma^{m}$ & $\begin{array}{l}\text { Elasticity of substitution between domestic and } \\
\text { imported goods in intermediate consumption }\end{array}$ & 0.4 & Atalay, 2017 \\
\hline $3 \quad \sigma^{Y}$ & $\begin{array}{l}\text { Elasticity of substitution between value added and } \\
\text { intermediate goods in the production function }\end{array}$ & 0 & Böhringer et al., 2015 \\
\hline 4 & $\sigma^{V A}$ & $\begin{array}{l}\text { Elasticity of substitution between different factors } \\
\text { in production of value added }\end{array}$ & 1 & Böhringer et al., 2015 \\
\hline 5 & $\sigma^{A}$ & $\begin{array}{l}\text { Elasticity of substitution between domestic and } \\
\text { imported goods in the Armington aggregation } \\
\text { function for production of final goods }\end{array}$ & 4 & Aguiar et al., 2016 \\
\hline
\end{tabular}

\section{Results: terms of trade decrease}

One of my principal interests is the quantification of terms of trade shock response of the Russian economy on a detailed CGE model calibrated with Russian inputoutput data. The assessment of effects of a terms of trade shock on the macro and industry level is completed with a help of a detailed computable general equilibrium model. Models of this class permit introduction of rich details and complexity of production structures, as well as optimising behaviour of economic agents.

\subsection{Scenario definition}

The Central scenario is a $10 \%$ decrease in world prices of crude oil, accompanied by a $3 \%$ decrease in the world price of natural gas, and a $8 \%$ decrease in the world price of petrochemical products.

Relationship between the world oil and gas prices. There is a growing literature on long-term relationship between global crude oil and natural gas

${ }^{5} \sigma^{V A}=1$ is the elasticity of substitution between different factors in production of value added. 
prices (Nick and Thoenes, 2014). Recently, the long-run oil-gas price relationship has been challenged quite often, as these two prices have shown evidence of decoupling from each other (Ramberg et al., 2017). Based on Zhang and Ji (2018), we adopt factor of 0.3 , describing relationship between change in the world price of oil and change of the world price of natural gas. Thus, in our Central scenario a $10 \%$ decrease in the world price of oil is accompanied with a $3 \%$ change in the world price of natural gas.

Relationship between the world oil and oil products' prices. Strong technological connections (Ramberg et al., 2017) between crude oil and oil products dictate relatively high factor of 0.8 describing relationship between crude oil and oil products world prices for Russian exports (Polanco Martínez et al., 2018). In our Central scenario, a 10\% decrease in the world price of crude oil is accompanied by a $8 \%$ decrease in the world price of oil products.

We can present Central scenario as a composition of three scenarios: 'Oil', 'Natural gas', and 'Petroleum products'. Each of these scenarios models decrease in the world prices of one separate product. Thus, the Central scenario is summarised as a simultaneous decrease in three world prices for Russian exports:

- Crude oil (scenario 'Oil': decrease of the world price for crude oil by 10\%).

- Natural gas (scenario 'Natural gas': decrease of the world price for natural gas by $3 \%)$.

- Petroleum products (scenario 'Petroleum products': decrease of the world price for petroleum products by $8 \%$ ).

\subsection{Simulation results: comparative static model}

Overall economic impact for the Central scenario in the settings of the static model is shown in the Table 6 in Appendix IV. The results are presented for the Central scenario and its components. Welfare changes associated with the Central scenario indicate a significant decrease in the welfare of the representative consumer up to $-1.17 \%$ of benchmark consumption level, or $-0.58 \%$ of the base year GDP.

Percentage change of the GDP in the Central scenario is of the same magnitude as representative consumer's decrease in welfare in terms of the benchmark GDP (-1.54\%).

Major driver of the decline in the GDP is government consumption (-4.28\%), due to fall in oil taxes (export tariffs). ${ }^{6}$ Decline in the household's consumption $(-1.17 \%)$ reflects households' income decline, caused by decline in remuneration of mobile factors of production (wage decreases by $-1.33 \%$, mobile capital rent - by $-0.73 \%)$. The most significant decline in income is the decline of rent of the specific capital in the oil industry by $-3.22 \%$. Investment decreases as well (by $-0.87 \%$ ).

\footnotetext{
${ }^{6}$ The model does not contain the fiscal rule mechanism. In other words, Central scenario describes the situation when state budget doesn't not receive transfers in the case of decrease of the world oil prices.
} 
The only component of the final demand that experiences growth is real aggregated exports (1.23\%), partly due to performance of the exchange rate $(+4.24 \%){ }^{7}$

The external closure of the model fixes trade balance in real terms and lets the exchange rate to adjust to changes in relative prices of exported and imported goods. The exchange rate is defined in units of local currency to units of foreign currency, thus an increase in the value of the exchange rate means depreciation of the local (domestic) currency. A decrease in the exchange rate means that domestic currency strengthens.

The Central scenario is associated with a $4.24 \%$ increase in the exchange rate. This means that all imported goods are $4.24 \%$ more expensive than in the base year.

The numeraire of the static model is a consumer price index (CPI), thus CPI change in all scenarios equals to zero. Since only relative prices matter in the CGE models, all other prices are quoted in terms of the numeraire (CPI in our case). Given that CPI is fixed, changes in the exchange rate reflect changes in the real exchange rate. In the Central scenario wages change by $-1.33 \%$ and return to mobile capital - by $-0.73 \%$.

Return to specific capital in extracting industries, or natural rent, decreases for crude oil production $(-3.22 \%)$, indicating reduction of production activities.

All other extracting sectors feel much better with increase in return to specific capital in the Central scenario. The resource rent in production of natural gas rises (4.2\%), as well as the resource rent in production of coal (4.26\%), and other mining activities (5.94\%).

Aggregated production index rises by $0.57 \%$. Agriculture production index rises by $0.08 \%$. Extraction production stays constant on the level of the base year. Manufacturing production index rises by $0.91 \%$, which indicates shift of the resources to manufacturing sector.

Services production index decreases by $-0.42 \%$. This is the consequence of decline in government spending, since government's demand drives total demand for services.

Changes induced by deterioration of the terms of trade lead to reallocation of mobile factors: workers change industries, as well as mobile capital. Though, the magnitude of reallocation is not significant: $0.66 \%$ of mobile capital and $1.14 \%$ of workers change sectors in the Central scenario.

\subsection{Simulation results: steady-state model}

The steady-state model is an extension of the comparative static model. The goal of the steady state calculation is to evaluate the upper bound (Rutherford and Tarr, 2003) on welfare changes associated with terms of trade deterioration for the Russian economy.

\footnotetext{
7 The exchange rate is defined as the ratio of the domestic currency to the foreign one, therefore, an increase in the value of the exchange rate reflects a weakening of the national currency.
} 
In the comparative static model the price of capital varies, while total supply of capital is fixed. In the steady-state model the mobile capital stock and investment demand are endogenously determined, while the price of capital is constant. In other words, the steady-state model solves for time-invariant capital stock. In the steady-state model optimal capital stock is such that cost of investment equals the discounted stream of rents on installed capital. ' "This can be viewed as a multi-sector version of the "golden rule" equilibrium' (Rutherford and Tarr, 2003).

Major difference between the results of comparative static and steady-state models is captured in the changes of investment demand. As a result of deterioration of the terms of trade, optimal capital stock for the economy decreases, causing investment demand to go down even further then in the comparative static case. There is a $-1.56 \%$ decrease in the total investment demand in the Central scenario of the steady-state model vs. decrease of $-0.87 \%$ in the comparative static case.

The effects induced by the ToT deterioration on the capital stock echo in total production index decreases. Thus, a decrease in the terms of trade pushes the economy to an inferior steady state, characterised by decrease in the welfare of a representative consumer, lower level of production, and consumption.

Overall economic impacts for the Central scenario in the settings of the steady-state model are shown in the Table 7 in Appendix IV. The results are presented for the Central scenario and its components.

Welfare changes associated with the Central scenario indicate a significant decrease in the welfare of the representative consumer up to $-2.46 \%$ of benchmark consumption level, or $-1.29 \%$ of the base year GDP. These results exceed welfare changes in the Central scenario of the static model and we can refer to these values as upper bound of possible changes in welfare in the dynamic modelling exercise (Rutherford and Tarr, 2003).

The percentage change of the GDP in the Central scenario of the steady-state model is of the same magnitude as a representative consumer's decrease in welfare in terms of the benchmark GDP (-2.51\%).

The decline in the GDP is driven by decrease in government consumption (-5.21\%). Private consumption declines as well (-2.46\%).

The external closure of the steady-state model is the same as in the static model, i.e. the trade balance is fixed in real terms and the exchange rate adjusts to changes in relative prices of exported and imported goods. The exchange rate is defined in unites of local currency to units of foreign currency, thus an increase in the value of the exchange rate means depreciation of the local (domestic) currency. A decrease in the exchange rate means that domestic currency strengthens.

The Central scenario of the steady-state model is associated with a $4.3 \%$ increase in the exchange rate causing prices of imported goods to rise proportionally.

The numeraire of the steady-state model is a consumer price index (CPI), thus, $\mathrm{CPI}$ change in all scenarios equals to zero. Since only relative prices matter in the

\footnotetext{
${ }^{8}$ In this version of the model depreciation is set to zero.
} 
computable general equilibrium models, all other prices are quoted in terms of the numeraire (CPI in our case). Given that CPI is fixed, changes in the exchange rate reflect changes in the real exchange rate.

Representative consumer's income comes from primary factors. In the Central scenario of the steady-state model wages change by $-2.6 \%$ and return to mobile capital - by $-0.08 \%$.

Return to specific capital in extracting industries, or natural rent decreases for crude oil production $(-4.02 \%)$, indicating reduction of production activities. All other extracting sectors feel much better with increase in return to specific capital in the Central scenario: the resource rent in production of natural gas rises (3.24\%), as well as the resource rent in production of coal (3.36\%) and other mining activities (5.14\%).

Aggregated production index decreases by $-0.347 \%$. Agriculture production index increases insignificantly (by $0.03 \%$ ), extraction production index decreases by $-0.05 \%$, manufacturing production index rises by $0.73 \%$. This indicates shift of the resources to manufacturing sector, along the same lines, which we saw in the static case. Though, increase in production of manufacturing doesn't outweigh decrease in all other parts of the economy, contrary to the result in the static model. The services production index decreases by $-1.05 \%$.

Changes induced by deterioration of the terms of trade lead to reallocation of mobile factors: workers change industries, as well as mobile capital. The magnitude of reallocation in the steady-state model is more significant than in the static one: $2 \%$ of mobile capital and $1.2 \%$ of workers change sectors in the Central scenario.

\subsection{Changes on the industry level}

\subsubsection{Output changes}

Changes on industry level are presented in Appendix IV (Tables 6-9). On the industry level we can trace the same tendencies that were obvious on the macro level: decrease in private consumption, decrease in imports, relative increase in exports, and associated with export dynamics changes in production. Exporting becomes a profitable alternative to stagnating domestic market. Though, this does not lead to an export-led growth.

Industrial changes in the comparative static (Appendix IV, Table 6) and steadystate (Appendix IV, Table 7) models describe similar pictures but have important differences. Industrial output change induced by the terms of trade deterioration depends on the cost structure of the industries and changes in domestic demand. The magnitude of changes in industry output is much bigger in the steady-state version of the model than in the static version. Partially this reflects much deeper changes in the economy under the assumption of the steady-state model: the reduction of installed capital induced by the ToT change and much deeper decrease in imports lead to a bigger reallocation of factors, which was discussed above. 


\subsubsection{Price changes}

I present changes in prices on the industry level in Appendix IV (Table 10). Tables contain changes in prices of output, industry revenues, costs of manufactured intermediates and intermediates services in production for the Central scenario of the static model. Given changes in prices on the industry level are a result of two main forces: decrease of domestic demand, due to decrease of disposable income of the representative consumer, and increase in prices, due to depreciation of the national currency.

The propagation of the exchange rate devaluation into production costs goes along the lines of the structure of the use of imported intermediates, as presented in Figure 5.

From the said figure it is evident that, according to the data in the system of national accounts, the dependence of the Russian economy on imports is not industry-based, but can be described as product-based. There is evident tendency of all industries to consume more imported leather products (s019) and imported office electronics (s30) than domestic ones. As a consequence, pass-through of exchange rate depreciation associated with terms of trade shock would be more in costs of those industries, which use those intermediate goods relatively more than others.

An evidence of this tendency can be traced in changes of cost indices of production presented in Appendix IV (Table 10). Average change in costs of intermediates across all industries is 0.21 . Imported services are almost absent from the intermediate consumption, there is no influence of exchange rate deterioration on the cost of intermediate services. So, a $4.3 \%$ increase in the real ${ }^{9}$ exchange rate corresponds to average increase of $0.2 \%$ in cost index of intermediate goods consumption.

\subsection{Validation of the model: historical simulations}

Validation of computable general equilibrium model is important and timeconsuming process. There are different ways to assure validity of computational models, and a CGE in particular. A computational model (Dixon and Rimmer, 2013):

(i) Should be computationally sound. Computational quality of the present model is ensured by numerous checks, including replication of the benchmark dataset.

(ii) Should use accurate up-to-date data. As discussed earlier, the most up-todate available data is used for the creation of the benchmark dataset.

(iii) Should adequately capture behavioural and institutional characteristics of the relevant part of the economy. A range of behavioural and institutional characteristics is used in the presented model based on the latest research on Russian economy.

\footnotetext{
${ }^{9}$ Note, that CPI is fixed as a numeraire in the Central scenario of the static model, thus, real and nominal values of the exchange rate coincide.
} 
Figure 5. Imports in intermediate consumption: darker cells correspond to higher share of imports in intermediate use by industry and by intermediate commodity group, benchmark dataset, 2011

s01 s02 s05 s10 oil gass112s12xs15s15xs16 s17 s18 s19 s20 s21 s22 s23 s24 s25 s26 s27 s28 s29 s30 s31

s01

$\mathrm{sO2}$

$\mathrm{sO5}$

s10

oil

gas

s112

s12x

s15

s15x

s16

s17

s18

s19

s20

s21

s22

s23

s24

s25

s26

s27

s28 
Continuation, Figure 5

s01

$\mathrm{s} 02$

s05

s10

oil

gas

s112

s12x

s15

s15x

s16

s17

s18

s19

s20

s21

s22

s23

s 24

s 25

s26

s27

s28

s29

s30

s31

s32

s33

s34

s35

s36x

$s 40$

s41

s45

trd

s55

trn

s63

564

s65x

s70

s71

s72

s73

574

s75

$\mathrm{s} 80$

585

s90

592

s93x s32 s33 s34 s35 s36xs40 s41 s45 trd s55 trn s63 s64 s65xs70 s71 s72 s73 s74 s75 s80 s85 s90 s91 s92 s93x

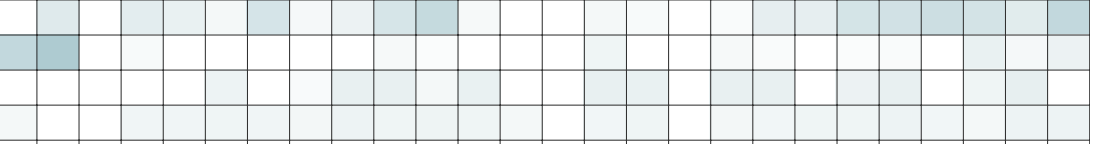

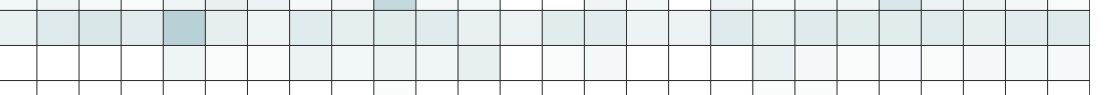
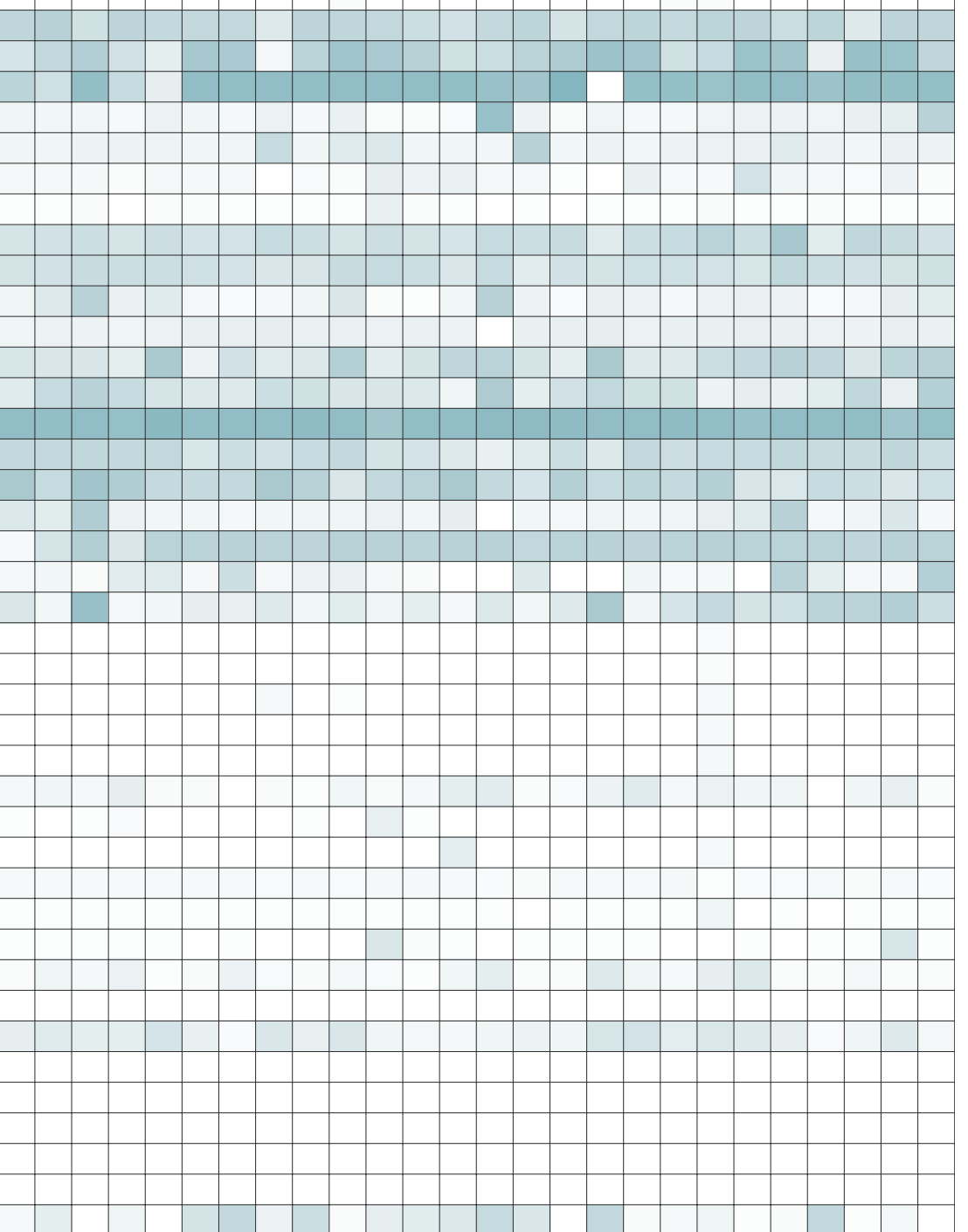
(iv) Should be consistent with history. In order to validate model's consistency, historical experiments have been conducted. The setting of the experiments and results are discussed below.

A historical scenario is defined as changes in exogenous parameters of the model that were observed in the data. Validation of the model is measured by the goodness of fit parameter. One of many possible measures of the goodness of fit is the 'average error' measure proposed by Dixon and Rimmer (2013):

$$
A E=\left(\frac{1}{N}\right) * \sum_{c}\left|f_{c}-a_{c}\right| /\left(1+\frac{a_{c}}{100}\right),
$$

where: $f_{c}$ - model forecast of the percentage change in the output of goods $c$, $a_{c}$ - statistics on change in output, $N$ - the number of product groups in the model.

As a benchmark value for the average error of a detailed industrial historical scenario results, Dixon and Rimmer (2013) use average error calculated for the USAGE model, a detailed computable general equilibrium model for the American economy. ${ }^{10}$ The benchmark value equals $\mathrm{AE}=19 \%$ (Dixon and Rimmer, 2013).

Design of the historical simulation is presented in Appendix IV (Table 11). The simulations differ in accounting for changes in the world prices of Russian exports, world prices of Russian imports, changes in the export taxes, share of specific capital in the economy, share of the specific capital in the extraction sector, and values of Armington elasticities. Scenarios 7 and 8 use Armington elasticities from the GTAP model (Hertel, 2013).

The most important element of the historical simulation is a correct assessment of changes in exogenous parameters of the model. In our case the most important exogenous parameters are world prices of exports and imports. The importance of these parameters for validation of the present model is based on the primary use of the model in estimation of the effect of the change in terms of trade for the Russian economy.

In order to calculate changes in export and import prices on the level of commodity groups presented in the model, several datasets were used:

1) CEPII TUV dataset (Gaulier et al., 2008);

2) UN COMTRADE;

3) EAEU detailed trade data on 10-digit HS code level;

4) IMF Commodity price database;

5) IMF Commodity Terms of Trade (Gruss and Kebhaj, 2019);

6) CBR database of main export prices of Russian exports.

Price data for exports and imports are highly volatile and the most timeconsuming effort is to exclude outliers. The resulting changes in export and import prices are presented in the Appendix III (Tables 4-5).

\footnotetext{
${ }^{10}$ Detailed description of the USAGE model is available at https://www.copsmodels.com/usage.htm
} 
One of important characteristics of the historical response of the Russian economy on the changes in terms of trade that occurred in 2014-2015 was stable real output of the extraction sector. As we saw earlier, this contradicted predictions of both static and steady-state models.

The simulation results presented in Appendix IV (Table 11) suggest that behaviour of Russian oil and gas extraction sector is explained by changes in export taxes, which are cut almost by half at the same time when world prices fall, thus, leaving the perceived dollar price of oil exports for firms in the industry almost unchanged. This situation is depicted in scenario 4. In a medium term time span, mimicked by $30 \%$ of all capital in the economy being specific, difference between model's forecast of output of oil and gas sector and historical values reported by Rosstat equals to $0.4 \%$. Further alternation of the model, including changes in the import prices, distorts the results.

There is a comparison of the results of the historical scenario 4 and a naïve model, which is a $5 \%$ proportional increase in all values of the industry output in 2011 (Appendix IV, Table 12). The naïve model has better average error (10.48\%) than any of the simulations above, difference between naïve prediction for the oil and gas industry $(1.6 \%)$ is bigger than for scenario $(-0.4 \%)$.

To the best of my knowledge, this is the first attempt to introduce validation procedure with historical data to the CGE analysis for the Russian economy. The results of the historical scenarios suggest that the presented computable general equilibrium model is valid for use of scenario estimation for the Russian economy. It could picture diverse industrial response on terms of trade shocks.

Historical scenarios stress importance of fiscal changes in estimating changes in industry output in times of terms of trade shocks, especially changes in export taxes in extraction industries.

\section{Conclusions}

This paper examines the impact of changes in world prices on the Russian economy. In particular, I am interested in the change in production as a result of changes in world prices for the main Russian export and import commodities.

A number of recent macro studies (Atalay, 2017; Acemoglu et al., 2017; Burstein et al., 2008) stress the importance of explicit introduction of the intermediates in the models assessing effects of external shocks, which is a wellestablished practice in the CGE methodology. Models of this class permit introduction of rich details and complex production structures as well as optimising behaviour of economic agents.

The model presented in the paper belongs to the class of CGE models. It has a detailed industry structure, which allows tracing the effect of changes in world prices on all aspects of the Russian economy. 
The results suggest a decrease of welfare of the representative consumer and real GDP with the deterioration of the terms of trade. In the Central scenario (a 10\% decrease in the world price of crude oil, a 3\% decrease in the world price of natural gas, and a $8 \%$ decrease in the world price of petroleum products) welfare of the representative consumer decreases by $-1.17 \%$ of benchmark consumption level, or $0.58 \%$ of the base year GDP in the comparative static model. Percentage change of the GDP in the Central scenario of the comparative static model is of the same magnitude as representative consumer's decrease in welfare in terms of the benchmark GDP (-1.55\%).

Welfare changes associated with the Central scenario of the steady-state model indicate a significant decrease in the welfare of the representative consumer up to $-2.64 \%$ of benchmark consumption level, or $-1.23 \%$ of the base year GDP. Percentage change of the GDP in the Central scenario of the steady-state model exceeds representative consumer's decrease in welfare in terms of the benchmark GDP (-2.51\%). The GDP response in the steady-state model is in line with estimates obtained in compatible work by Polbin (2017).

These results exceed welfare changes in the Central scenario of the static model, and we can refer to these values as upper bound of possible changes in welfare in the dynamic modelling exercise (Rutherford and Tarr, 2003).

\section{Appendices are available at http://rjmf.econs.online/en; dx.doi.org/10.31477/rjmf.202002.43}

\section{References}

Acemoglu, D., Ozdaglar, A. and Tahbaz-Salehi, A. (2017). Microeconomic Origins of Macroeconomic Tail Risks. American Economic Review, 107 (1), pp. 54-108. doi: 10.1257/aer.20151086

Aghion, P., Bacchetta, P. and Banerjee, A. (2000). A Simple Model of Monetary Policy and Currency Crises. European Economic Review, 44(4-6), pp. 728-738. doi: 10.1016/S0014-2921(99)00053-7

Aguiar, A., Narayanan, B. and McDougall, R. (2016). An Overview of the GTAP 9 Data Base. Journal of Global Economic Analysis, 1(1), pp. 181-208. doi: 10.21642/jgea.010103af

Alekseev, A., Sokolov, D., Turdyeva, N. and Yudaeva, K. (2004). Estimating the Effects of EU Enlargement, WTO Accession and Formation of FTA with EU or CIS on Russian Economy. Available at: https://www.gtap.agecon.purdue.edu/resources/ download/1887.pdf [accessed on 5 September 2019].

Alekseev, A., Turdyeva, N. and Yudaeva, K. (2003). Estimation of the Russia's Trade Policy Options with the Help of the Computable General Equilibrium Model. NES Working Papers, N42. Available at: https://www.nes.ru/files/Preprints-resh/WP42-CGE.pdf [accessed on 5 September 2019]. 
Alekseyev, A., Volchkova, N., Denisova, I., Levin, I., Turdyeva, N. and Khaleeva, J. (2004). Mikroekonomicheskaya Otsenka Posledstviy Nalogovoy Reformy [Microeconomic Assessment of the Consequences of the Tax Reform]. CEFIR Policy Papers, N 19. [In Russian]. Available at: https://www.nes.ru/files/ research/cefir/policypapers/PP19.pdf [accessed on 5 September 2019].

Armington, P. S. (1969). A Theory of Demand for Products Distinguished by Place of Production. International Monetary Fund Staff Papers, 16(1), pp. 159-178. doi: $10.2307 / 3866403$

Arrow, K. J., Chenery, H. B., Minhas, B. S. and Solow, R. M. (1961). Capital-Labor Substitution and Economic Efficiency. The Review of Economics and Statistics, 43(3), pp. 225-250.

Atalay, E. (2017). How Important Are Sectoral Shocks? American Economic Journal: Macroeconomics, 9 (4), pp. 254-280. doi: 10.1257/mac.20160353

Badasen, P., Kartaev, F. and Khazanov, A. (2015). Ekonometricheskaya Otsenka Vliyaniya Valyutnogo Kursa Rublya na Dinamiku Vypuska [Econometric Assessment of the Ruble Exchange Rate Impact on the Output]. Dengi i Kredit, 7, pp. 41-49. [In Russian]. Available at: https://rjmf.econs.online/archive/2015/7/ [accessed on 5 September 2019].

Bakhtizin A.R. (2003). Vychislimaya model' 'Rossiya: Tsentr - Federal'nyye okruga' [Computable model 'Russia: Center - Federal Districts']. CEMI RAS Preprint, N 151. [In Russian].

Berezinskaya, O. and Vedev, A. (2015). Dependency of the Russian Industry on Imports and the Strategy of Import Substitution Industrialization. Voprosy Ekonomiki, 1, pp. 103-115. [In Russian]. doi: 10.32609/0042-8736-2015-1-103-115

Besstremyannaya, G. and Bakhtizin, A. (2006). Tax Policy Measures for Education and Healthcare Sectors of Russian Economy: Computable General Equilibrium Analysis. CEMI RAS Working Papers, N 208.

Böhringer, C., Rutherford, T. F., Tarr, D. G. and Turdyeva, N. (2015). Market Structure and the Environmental Implications of Trade Liberalization: Russia’s Accession to the World Trade Organization. Review of International Economics, 23(5), pp. 897-923. doi: $10.1111 /$ roie. 12197

Burstein, A., Kurz, C. and Tesar, L. (2008). Trade, Production Sharing, and the International Transmission of Business Cycles. Journal of Monetary Economics, 55(4), pp. 775-795. doi: 10.1016/j.jmoneco.2008.03.004

Bussolo, M. and Luongo, P. (2017). The Distributive Impact of Terms of Trade Shocks. World Bank Policy Research Working Papers, N 8016.

Carbone, J. C., Helm, C. and Rutherford, T. F. (2004). Self-Enforcing Agreements and International Trade in Greenhouse Gas Emission Rights. doi: 10.2139/ssrn.609042

De V. Cavalcanti, T. V., Mohaddes, K. and Raissi, M. ( 2015). Commodity Price Volatility and the Sources of Growth. Journal of Applied Econometrics, 30(6), pp. 857-73. doi: $10.1002 /$ jae. 2407 
Devarajan, S. and Robinson, S. (2013). Contribution of Computable General Equilibrium Modeling to Policy Formulation in Developing Countries. In: P. B. Dixon and D. W. Jorgenson, eds., Handbook of Computable General Equilibrium Modeling. Elsevier, Vol. 1, pp. 277-301. doi.org/10.1016/B978-0-444-59568-3.00005-5

Dixon, P. B. and Rimmer, M. T. (2013). Validation in Computable General Equilibrium Modeling. In: P. B. Dixon and D. W. Jorgenson, eds., Handbook of Computable General Equilibrium Modeling. Elsevier, Vol. 1, pp. 1271-1330. doi: 10.1016/B978-0-444-59568-3.00019-5

Dixon, P. B. and Rimmer, M. T. (2016). Johansen's Legacy to CGE Modelling: Originator and Guiding Light for 50 Years. Journal of Policy Modeling, 38(3), pp. 421-435. doi.org/10.1016/j.jpolmod.2016.02.009.

Dixon, P. B., Koopman, R. B. and Rimmer, M. T. (2013). The MONASH Style of Computable General Equilibrium Modeling: A Framework for Practical Policy Analysis. In: P. B. Dixon and D. W. Jorgenson, eds., Handbook of Computable General Equilibrium Modeling. Elsevier, Vol. 1, pp. 23-103. doi: 10.1016/B978-0-444-59568-3.00002-X

Dong, B., Ma, X., Wang, N. and Wei, W. (2017). Impacts of Exchange Rate Volatility and International Oil Price Shock on China's Regional Economy: A Dynamic CGE Analysis. Energy Economics, 86, article 103762. doi: 10.1016/j.eneco.2017.09.014

Dynnikova, O. (2000). Makroekonomicheskiye Perspektivy Ukrepleniya Rublya i Valyutnaya Politika [Macroeconomic Prospects for Ruble Appreciation and Monetary Policy]. Moscow: Economic Expert Group. [In Russian]. Available at: http://www.eeg.ru/downloads/BOOK/b05.pdf [accessed on 5 September 2019].

Easterly, W., King, R., Levine, R. and Rebelo, S. (1994). Policy, Technology Adoption and Growth. NBER Working Papers, N 468. https://doi.org/10.3386/w4681

Fehr, H. (2016). CGE Modeling Social Security Reforms. Journal of Policy Modeling, 38(3), pp. 475-494. doi: 10.1016/j.jpolmod.2016.02.007

Fehr, H., Jokisch, S., Kallweit, M., Kindermann, F. and Kotlikoff, L.J. (2013). Generational Policy and Aging in Closed and Open Dynamic General Equilibrium Models. In: P. B. Dixon and D. W. Jorgenson, eds., Handbook of Computable General Equilibrium Modeling. Elsevier, Vol. 1, pp. 1719-1800. doi: 10.1016/B978-0-444-59568-3.00027-4

Gatti, D. D., Gallegati, M., Greenwald, B. C. and Stiglitz, J. E. (2007). Net Worth, Exchange Rates, and Monetary Policy: The Effects of a Devaluation in a Financially Fragile Environment. NBER Working Papers, N 13244. doi: 10.3386/w13244

Gaulier, G., Martin, J., Méjean, I. and Zignago, S. (2008). International Trade Price Indices. CEPII Working Paper, N 10.

Giesecke, J. A. and Madden, J. R. (2013). Regional Computable General Equilibrium Modeling. In: P. B. Dixon and D. W. Jorgenson, eds., Handbook of Computable General Equilibrium Modeling. Elsevier, Vol. 1, pp. 379-475. doi: 0.1016/B978-0-444-59568-3.00007-9

Greenwald, B. C. and Stiglitz, J. E. (1993). Financial Market Imperfections and Business Cycles. The Quarterly Journal of Economics, 108(1), pp. 77-114. doi: 10.2307/2118496 
Gruss, B. and Kebhaj, S. (2019). Commodity Terms of Trade: A New Database. IMF Working Papers, N 21.

Gylfason, T. and Schmid, M. (1983). Does Devaluation Cause Stagflation? The Canadian Journal of Economics / Revue canadienne d'Economique, 16(4), pp. 641-654. doi: $10.2307 / 135045$

Hertel, T. (2013). Global Applied General Equilibrium Analysis Using the Global Trade Analysis Project Framework. In: P. B. Dixon and D. W. Jorgenson, eds., Handbook of Computable General Equilibrium Modeling. Elsevier, Vol. 1, pp. 815-76. doi: 10.1016/B978-0-444-59568-3.00012-2

Holmøy, E. and Strøm, B. (2013). Computable General Equilibrium Assessments of Fiscal Sustainability in Norway. In: P. B. Dixon and D. W. Jorgenson, eds., Handbook of Computable General Equilibrium Modeling. Elsevier, Vol. 1, pp. 105-158. doi: 10.1016/B978-0-444-59568-3.00003-1

Horridge, M., Meeraus, A., Pearson, K. and Rutherford, T. F. (2013). Solution Software for Computable General Equilibrium Modeling. In: P. B. Dixon and D. W. Jorgenson, eds., Handbook of Computable General Equilibrium Modeling. Elsevier, Vol. 1, pp. 1331-1381. https://doi.org/10.1016/B978-0-444-59568-3.00020-1.

Idrisov, G., Ponomarev, Y. and Sinelnikov-Murylev, S. (2015). Terms of Trade and Russian Economic Development. Ekonomicheskaya Politika, 10(3), pp. 7-37. [In Russian]. doi: 10.18288/1994-5124-2015-3-01

International Monetary Fund (2017a). World Economic Outlook: Gaining Momentum? Washington, April.

International Monetary Fund (2017b). Russian Federation: Selected Issues. IMF Country Report No. 17/198.

Jensen, J., Rutherford, T. F. and Tarr, D. G. (2004). The Impact of Liberalizing Barriers to Foreign Direct Investment in Services: The Case of Russian Accession to the World Trade Organization. World Bank Policy Research Working Papers, N 3391. doi: 10.1596/1813-9450-3391

Kadochnikov, P., Sinelnikov-Murylev, S. and Chetverikov, S. (2003). Importozameshchenie $v$ Rossiyskoy Federatsii v 1998-2002 gg. [Import Substitution in the Russian Federation in 1998-2002]. Moscow: Gaidar Institute for Economic Policy. [In Russian]. Available at: https://www.iep.ru/files/text/working_papers/62.pdf [accessed on 5 September 2019].

Kartaev P. (2009). Ekonometricheskoye Modelirovaniye Vzaimosvyazi Kursa Rublya i Dinamiki VVP [Econometric Modeling of the Relationship between the Ruble Exchange Rate and GDP Dynamics]. Vestnik Moskovskogo universiteta, Seriya 6: Ekonomika, 2, pp. 57-67.

Kolik, A., Radziwill, A. and Turdyeva, N. (2015). Improving Transport Infrastructure in Russia. OECD Economics Department Working Papers, N 1193. doi: $10.1787 / 5 j s 4 \mathrm{hmcs} 3 \mathrm{mxp}$-en

Kontorovich, V. (2001). Vzaimosvyaz' Real'nogo Kursa Rublya i Dinamiki Promyshlennogo Proizvodstva v Rossii [The Relationship of the Ruble Real Exchange Rate and the Dynamics of Industrial Production in Russia]. Ekonomicheskii 
zhurnal VShE, 3, pp. 363-74. [In Russian]. Available at: https://ej.hse.ru/da ta/2010/12/31/1208180016/05_03_08.pdf [accessed on 5 September 2019].

Kose, M. A. (2002). Explaining Business Cycles in Small Open Economies. Journal of International Economics, 56 (2), pp. 299-327. doi: 10.1016/S0022-1996(01)00120-9

Lofgren, H., Harris, R.L., Robinson, S., Thomas, M. and El-Said, M. (2002). A Standard Computable General Equilibrium (CGE) Model in GAMS. Microcomputers in Policy Research, N 5. Washington: International Food Policy Research Institute.

Makarov, V. L. (1999). Vychislimaya Model' Rossiyskoy Ekonomiki (RUSEC). [Computable model of the Russian economy (RUSEC)]. CEMI RAS Preprint, N 69. [In Russian].

Mendoza, E. G. (1995). The Terms of Trade, the Real Exchange Rate, and Economic Fluctuations. International Economic Review, 36(1), pp. 101-137. doi: $10.2307 / 2527429$

Nick, S. and Thoenes, S. (2014). What Drives Natural Gas Prices? - A Structural VAR Approach. Energy Economics, 45, pp. 517-527. doi: 10.1016/j.eneco.2014.08.010.

Polanco Martínez, J. M., Abadie, L. M. and Fernández-Macho, J. (2018). A MultiResolution and Multivariate Analysis of the Dynamic Relationships between Crude Oil and Petroleum-Product Prices. Applied Energy, 228, pp. 1550-1560. doi: 10.1016/j.apenergy.2018.07.021

Polbin, A. (2017). Econometric Estimation of the Impact of Oil Prices Shock on the Russian Economy in VECM Model. Voprosy Ekonomiki, 10, pp. 27-49. [In Russian]. doi: 10.32609/0042-8736-2017-10-27-49

Pyatt, G. (1991). Fundamentals of Social Accounting. Economic Systems Research, 3(3), pp. 315-341. doi: 10.1080/09535319100000024

Pyatt, G. and Round, J. I. (1985). Social Accounting Matrices: A Basis for Planning. Washington, D.C.: The World Bank.

Ramberg, D. J., Henry Chen, Y.-H., Paltsev, S. and Parsons, J. E. (2017). The Economic Viability of Gas-to-Liquids Technology and the Crude Oil-Natural Gas Price Relationship. Energy Economics, 63, pp. 13-21. doi: 10.1016/j.eneco.2017.01.017

Reinsdorf, M. B. (2010). Terms of Trade Effects: Theory and Measurement. Review of Income and Wealth, 56(s1), pp. S177-205. doi: 10.1111/j.1475-4991.2010.00384.x

Rose, A. and Liao, S.-Y. (2005). Modeling Regional Economic Resilience to Disasters: A Computable General Equilibrium Analysis of Water Service Disruptions. Journal of Regional Science, 45(1), pp. 75-112. doi: 10.1111/j.0022-4146.2005.00365.x

Rosstat (2017). Natsional'nyye Scheta Rossii v 2011-2016 Godakh [National Accounts of Russia in 2011-2016]. Moscow: Rosstat.

Rutherford, T. and Tarr, D. (2006). Regional Impacts of Russia's Accession to the World Trade Organization. World Bank Policy Research Working Paper, N 4015.

Rutherford, T. F. and Paltsev, S. (1999). From an Input-Output Table to a General Equilibrium Model: Assessing the Excess Burden of Indirect Taxes in Russia. Department of Economics, University of Colorado.

Rutherford, T. F. and Tarr, D. G. (2003). Regional Trading Arrangements For Chile: Do the Results Differ with a Dynamic Model? Economie Internationale, 94-95, pp. 261-82. 
Rutherford, T. F., Tarr, D. G. and Shepotylo, O. (2005). Poverty Effects of Russia's WTO Accession: Modeling 'Real' Households and Endogenous Productivity Effects. World Bank Policy Research Working Papers, N 3473. doi: 10.1596/1813-9450-3473

Schmitt-Grohé, S. and Uribe, M. (2018). How Important Are Terms-of-Trade Shocks? International Economic Review, 59(1), pp. 85-111. doi:10.1111/iere.12263

Shibusawa, H. and Miyata, Y. (2011). Evaluating the Dynamic and Spatial Economic Impacts of an Earthquake: A CGE Application to Japan. Regional Science Inquiry, III(2), pp. 13-25.

Tarr, D. G., Shepotylo, O. and Kouduyarov, T. (2005). The Structure of Import Tariffs in Russia: 2001-2003. Washington, D.C.: World Bank Group. Available at: http://documents.worldbank.org/curated/en/751091484047916649/The-structure-ofimport-tariffs-in-Russia-2001-2003 [accessed on 5 September 2019].

Timilsina, G. R. (2015). Oil Prices and the Global Economy: A General Equilibrium Analysis. Energy Economics, 49, pp. 669-675. doi: 10.1016/j.eneco.2015.03.005

Tokarick, S. (2014). A Method for Calculating Export Supply and Import Demand Elasticities. Journal of International Trade and Economic Development, 23(7), pp. 1059-1087. doi: 10.1080/09638199.2014.920403

Vdovichenko, A., Dynnikova, O. and Subbotin, V. (2003). O Vliyanii Real'nogo Obmennogo Kursa na Razlichnyye Sektora [On the Effect of the Real Exchange Rate on Various Sectors of Russian Economy]. Moscow: Economic Expert Group, 28 August. [In Russian]. Available at: http://www.eeg.ru/downloads/ PUBLICATIONS/ANALYTICS/a20030828.pdf [accessed on 5 September 2019].

Volchkova, N., Gorshkova, E., Lobanov, S., Makrushin, A., Turdyeva, N. and Khaleeva, J. (2006). Otsenka Posledstviy Reformirovaniya Sistemy Sotsial'nykh Garantiy: Monetizatsiya L'got i Reforma ZHKKH [Assessing the Consequences of Reforming the System of Social Guarantees: Monetization of Benefits and Housing Reform]. CEFIR Policy Papers, N 25. Available at: https://www.nes.ru/files/research/ cefir/policypapers/PP25.pdf [accessed on 5 September 2019].

World Bank Group (2015). Balancing Economic Adjustment and Transformation. Russia Economic Report, N 34.

Zemnitsky, A. (2003). Otsenka Posledstviy Ustraneniya Netarifnykh Bar'yerov dlya Inostrannykh Kompaniy v Sektore Uslug Rossiyskoy Ekonomiki: Strukturnyy Podkhod [Assessing the Consequences of Eliminating Non-Tariff Barriers for Foreign Companies in the Services Sector of the Russian Economy: A Structural Approach]. NES Working Papers, N 35. Available at: https://www.nes.ru/files/Preprints-resh/ WP35.pdf [accessed on 5 September 2019].

Zhang, D. and Ji, Q. (2018). Further Evidence on the Debate of Oil-Gas Price Decoupling: A Long Memory Approach. Energy Policy, 113, pp. 68-75. doi: $10.1016 /$ j.enpol.2017.10.046

Zodrow, G. R. and Diamond, J. W. (2013). Dynamic Overlapping Generations Computable General Equilibrium Models and the Analysis of Tax Policy: The Diamond-Zodrow Model. In: P. B. Dixon and D. W. Jorgenson, eds., Handbook of Computable General Equilibrium Modeling. Elsevier, Vol. 1, pp. 743-813. doi: 10.1016/B978-0-444-59568-3.00011-0 